\title{
OBSZARY KONCENTRACJI BEZROBOCIA W PRZESTRZENI LODZI
}

\section{THE AREAS OF CONCENTRATION OF UNEMPLOYMENT IN THE SPACE OF ŁÓDŹ}

\author{
Nr DOI: $10.25167 / \mathrm{sm} 2017.026 .03 \quad$ s. $39-50$
}

\begin{abstract}
ABSTRAKT: Współczesne miasto jest bardzo zróżnicowane społeczno-przestrzennie. Na podstawie badań wielu socjologów i geografów powszechnie znana jest teza o istnieniu silnych relacji między bezrobociem i przestrzenią. Podstawowym pytaniem badawczym jest: w jaki sposób / za pomocą jakich narzędzi można skutecznie i obiektywnie zidentyfikować hotspoty bezrobocia w przestrzeni miasta? Obszarem badanym w poszukiwaniu hotspotów w Łodzi była Strefa Wielkomiejska. Jest to obszar stanowiący centrum miasta, który obejmuje swym zasięgiem zabudowę historyczną, stanowiącą obszar tożsamości miasta. W artykule dokonano przeglądu technik GIS, dzięki którym można dokonać wyróżnienia hotspotów. Okazało się, że najlepiej dopasowane hotspoty uzyskano przy zastosowaniu grupowania hierarchicznego metodą najbliższego sąsiada oraz estymacji gęstości jądrowej. Zgodnie z oczekiwaniami najbardziej naznaczone bezrobociem okazało się ścisłe centrum Łodzi. Ze wszystkich zidentyfikowanych w Strefie Wielkomiejskiej miejsc koncentracji najwięcej bezrobotnych mieszkało na obszarze hotspotu, którego centralne miejsce zajmuje ul. Wschodnia.
\end{abstract}

SŁOWA KLUCZOWE: koncentracja przestrzenna, bezrobocie, hotspot, strefa wielkomiejska, Łódź

ABSTRACT: The modern city is greatly socio-spatially diverse. On the basis of accomplishments of many sociologists and geographers, it is a commonly known thesis that there exists a strong relationship between unemployment and space. The basic question of the research is: In what manner, or using what tools, can one effectively and objectively identify places of concentration (hotspots) of unemployment in city space? The part of Łódź studied in the study was the Metropolitan Area - the area which makes up the city centre and includes historical buildings that represent the city's identity. In the article, a review of GIS techniques is made, thanks to which one can differentiate concentrations of unemployment. It turns out that the most accurate hotspots were obtained by employing the hierarchical grouping method with the nearest neighbour technique and the kernel density estimation. In accordance with the expectations, the very centre of Łódź turns out to be affected by unemployment the most. Of all the places of concentrated unemployment identified in the Metropolitan Area, the hotspot with the highest number of unemployed was found in the area along Wschodnia Street.

KEY WORDS: spatial concentration, unemployment, hotspot, metropolitan area, Łódź

\footnotetext{
* Uniwersytet Łódzki, Wydział Nauk Geograficznych, Zakład Geografii Gospodarczej i Polityki Społecznej, e-mail: stanislaw.mordwa@geo.uni.lodz.pl.
} 


\section{Wprowadzenie}

Po 1989 r. pojawiły się w Polsce nowe źródła i przejawy patologii, które były wynikiem zmian społeczno-ekonomicznych, kulturowych i politycznych oraz konsekwencją transformacji ustrojowej i przejścia do gospodarki rynkowej. Największe społeczne koszty transformacji związane były z gwałtownym wzrostem bezrobocia. Jak pisze Eugeniusz Kwiatkowski (2002, s. 20), bezrobocie należy do najtrudniejszych do rozwiązania problemów społeczno-gospodarczych, gdyż związane jest z brakiem pracy zarobkowej wśród osób będących w wieku produkcyjnym, które są zdolne i gotowe do pracy oraz pracy tej poszukują. Bezrobocie jest trudnym problemem, ponieważ znajduje swoje odbicie w wielu aspektach życia ludzi, nie można go traktować wyłącznie w kategoriach ekonomicznych. Przede wszystkim następuje obniżenie poziomu konsumpcji (w tym dóbr podstawowych), co wpływa na pogorszenie się poziomu życia znacznych grup społecznych. Utrata pracy i trudności ze znalezieniem nowej mogą także powodować u ludzi pesymizm i apatię, problemy zdrowotne oraz finansowe. Następstwem tego jest pojawienie się takich stanów i uczuć jak: depresja, lęk przed przyszłością, stres, rozgoryczenie, poczucie wykluczenia, popadanie w nałogi, poniżenie. Niski poziom życia i natężenie zaburzeń emocjonalnych przekłada się z kolei na stan kondycji fizycznej i ogólny stan zdrowia osób, a także w szerszym zakresie na coraz gorsze funkcjonowanie rodzin, które przestają spełniać swoje funkcje. Bezrobocie zatem to zjawisko, w przypadku którego należy rozpatrywać jego negatywny wpływ na życie osób, rodzin i całego społeczeństwa. Przy znacznych rozmiarach oraz wydłużaniu się okresu pozostawania bez pracy wpływa ono na pojawienie się różnego rodzaju niepokojów społecznych, zjawiska nędzy czy braku nadziei na poprawę sytuacji.

Według Banku Danych Lokalnych trend spadkowy stopy bezrobocia rejestrowanego w Polsce miał miejsce do 2008 r., kiedy wyniosła ona 9,5\%. Trend ten był w dużej mierze spowodowany ówczesnym ożywieniem gospodarczym, dużą skalą emigracji zarobkowej oraz wykorzystywaniem środków z funduszy unijnych wspierających aktywność na rynku pracy. Niestety w kolejnych latach rejestrowano coroczny wzrost stopy bezrobocia, aż do roku 2013, gdy wyniosła ona 13,4\%. Wśród przyczyn tego wzrostu wymienia się: spowolnienie gospodarcze, rosnące pozapłacowe koszty pracy niesprzyjające zatrudnianiu na podstawie umów o pracę oraz niedostosowanie kwalifikacji pracowników do potrzeb zmieniającego się rynku pracy. Na koniec 2015 r. stosunek liczby zarejestrowanych bezrobotnych do liczby ludności aktywnej zawodowo wyniósł już tylko 9,7\%, zbliżając się do poziomu z roku 2008. W Łodzi zmiany poziomu stopy bezrobocia były identyczne jak te opisane dla Polski. Jednak w przypadku tego miasta były corocznie niższe o kilka punktów procentowych. I tak w 2008 r. stopa bezrobocia wyniosła 6,8\%, w 2013 r. - 12,3\%, a w 2015 r. osiągnęła poziom 9,5\%.

Współczesne miasto jest bardzo zróżnicowane społecznie i przestrzennie. Jak pisał Aleksander Wallis: „Miasto jest narzędziem nierówności społecznej. Powstaje pod wpływem tych nierówności, ułatwia je i potęguje” (Wallis 1971, s. 23). Na gruncie geografii społecznej miast i nauk pokrewnych wielokrotnie już zauważano, że różne 
patologie społeczne (w tym bezrobocie i bieda) związane są z „gorszymi” obszarami miasta. Do najważniejszych osiągnięć teoretycznych opisujących podstawy funkcjonowania obszarów koncentracji patologicznych zjawisk społecznych można zaliczyć: teorię dezorganizacji społecznej, koncepcję obszarów społecznych miasta (E. Shewky, W. Bell, S. Williams), koncepcję zbiorowej skuteczności R. Sampsona, teorię „wybitych szyb” G. Kellinga i J. Wilsona czy model ponowoczesnej struktury miasta M. Deara. Także na podstawie wyników badań polskich socjologów i geografów można sformułować kilka prawidłowości związanych z występowaniem patologii społecznych w polskich miastach. Po pierwsze, do obszarów problemowych w miastach należą przede wszystkim centra miast oraz osiedla wielkoblokowe, starsze osiedla blokowe, obszary podmiejskie (położone wzdłuż mało ruchliwych ulic o peryferyjnym położeniu oraz wzdłuż tras wylotowych), a także dawne osiedla przyzakładowe. Ponadto utrzymywanie się obszarów problemowych w centrach polskich miast ma miejsce od okresu międzywojennego. Tak zwane enklawy biedy charakteryzują się dekapitalizacją przestrzeni mieszkaniowej, bezrobociem, uzależnieniem mieszkańców od pomocy społecznej, nasileniem zachowań patologicznych - przestępczości, alkoholizmu itp. (Bartnicki 1991, Czekaj 1991, Skorupowa, Czepczyński 1999, Węcławowicz 2001, Grotowska-Leder 2001, Prawelska-Skrzypek, Porębski 2003, Kotus 2005, Zborowski 2010, Weltrowska, Kisiała 2014, Mordwa 2013, 2014).

Wzajemny układ różnorodnych niekorzystnych zjawisk prowadzących do przestrzennej i społecznej degradacji centralnych obszarów polskich miast opracował Andrzej Zborowski (2010, s. 78). W ujętym przez niego cyklu degradacji śródmieść niekorzystne procesy w polskich miastach, a szczególnie w ich śródmieściach, sięgają okresu powojennego. Wówczas zanegowano prawo własności wielu nieruchomości i dokonano komunalizacji lub nacjonalizacji dotychczas prywatnego budownictwa czynszowego. Nowi właściciele wykazali brak zainteresowania starą substancją mieszkaniową (priorytetami były obszary przemysłowe i wielkogabarytowe osiedla blokowe), co w powiązaniu z brakiem środków na remonty doprowadziło do jej znacznej degradacji materialnej (substancji budowlanej i infrastruktury technicznej). Oprócz opisanych przemian dokonujących się w warstwie urbanistyczno-infrastrukturalnej oraz prawno-własnościowej i administracyjnej cykl degradacji śródmieść rozegrał się także na płaszczyznach ekonomicznej i społecznej. W wymiarze ekonomicznym opisywany obszar miasta w okresie transformacji charakteryzował się niskim poziomem przedsiębiorczości, któremu towarzyszył upadek uprzednio istniejących tutaj usług i handlu. Jednak najwięcej różnorodnych przemian i procesów doznały śródmieścia $\mathrm{w}$ warstwie społecznej. Obszary te zostały intensywnie zasiedlone po drugiej wojnie światowej, przede wszystkim ludnością o niskim kapitale społecznym, w tym także bardzo słabo wykształconą ludnością ze wsi. Doprowadziło to do ogólnego wzrostu gęstości zaludnienia, która znalazła swój wymiar również w postaci przeludnienia mieszkań. Młodzi, lepiej sytuowani i wykształceni mieszkańcy śródmieść od lat 70. XX w. zaczęli emigrować - początkowo do osiedli blokowych, a później na przedmieś cia, co dodatkowo uwypukliło skalę problemów społecznych centrów miast. Obecnie 
obserwowane starzenie się społeczeństw dużych miast prowadzi do depopulacji głównie tych obszarów, które charakteryzowały się najniższym poziomem i jakością życia, czyli śródmieść. Postępujące tutaj skumulowanie zjawisk patologicznych prowadzi dodatkowo do stygmatyzacji i etykietowania tych obszarów, co nie pozwala na widzenie ich przyszłości w pozytywnych barwach. Do zjawisk patologicznych stwarzających najwięcej problemów społeczno-przestrzennych autor cyklu degradacji śródmieść zaliczył: bezrobocie, niepełne rodziny, ubóstwo i przestępczość.

W przypadku badania bezrobocia (często w połączeniu z ogólniejszą problematyką biedy) od wielu lat stosowane jest podejście przestrzenne (Stach, Wysocka 2014). W geografii społecznej miast wyjaśniane jest nielosowe rozmieszczenie miejsc zamieszkania bezrobotnych. Wraz z ich analizą pojawiła się potrzeba obiektywnego podejścia do wyznaczania miejsc, które koncentrują bezrobotnych - hotspotów bezrobocia ${ }^{1}$. Głównym zadaniem w identyfikacji hotspotów bezrobocia jest ocena stopnia losowości rozkładu przestrzennego danych. Większość dostępnych programów udostępnia różne sposoby rozróżnienia, czy rozmieszczenie zjawisk jest jednolite (zgodne z rozmieszczeniem przypadkowym), czy też istnieją wyraźnie skupiska przestrzenne. Za ich pomocą można wykrywać wzorce rozmieszczenia bezrobotnych w przestrzeni i kojarzyć je z innymi zjawiskami. Celem tego opracowania jest weryfikacja hipotezy, zgodnie z którą w przestrzeni Łodzi mamy do czynienia z wyraźnymi dysproporcjami w rozmieszczeniu osób bezrobotnych. Podjęta została zatem próba weryfikacji przydatności różnych technik wyznaczenia miejsc szczególnej koncentracji bezrobocia (hotspotów) w Strefie Wielkomiejskiej oraz charakterystyka wybranych obszarów problemowych.

\section{Obszar badań i źródło informacji}

Obszarem badanym w poszukiwaniu hotspotów w Łodzi będzie Strefa Wielkomiejska (Strefa) (rysunek 1). Zgodnie ze Strategią przestrzennego rozwoju Łodzi 2020+ na obszarze stanowiącym centrum miasta wyznaczono strefę, która obejmuje swym zasięgiem zabudowę historyczną, stanowiącą obszar tożsamości miasta. W dokumencie uchwalonym przez Radę Miasta napisano: „[w] obszarze zabytkowej tkanki zabudowy Strefy Wielkomiejskiej intensyfikują się problemy społeczne, które są dużym wyzwaniem rewitalizacyjnym i wymagają zintegrowanych działań samorządu i podmiotów prywatnych. Rozwiązanie choć części z tych problemów i odpowiednie lansowanie zabytku jako dobrej podstawy do inwestycji jest w stanie diametralnie poprawić kondycję Miasta”. Strefa ta, zgodnie z przyjętym przez Radę Miasta dokumentem, wymaga

\footnotetext{
1 Termin hotspot używany jest dla określenia szczególnie małych jednostek przestrzennych, charakteryzujących się wysokim natężeniem różnych zjawisk. Tym terminem określano np. miejsca szczególnie dużej aktywności wulkanicznej, miejsca o dużej bioróżnorodności, ze szczególnie wysokim natężeniem zjawisk przestępczych, a Silicon Valley w Kalifornii nazwano hotspotem rozwoju wysokich technologii.
} 


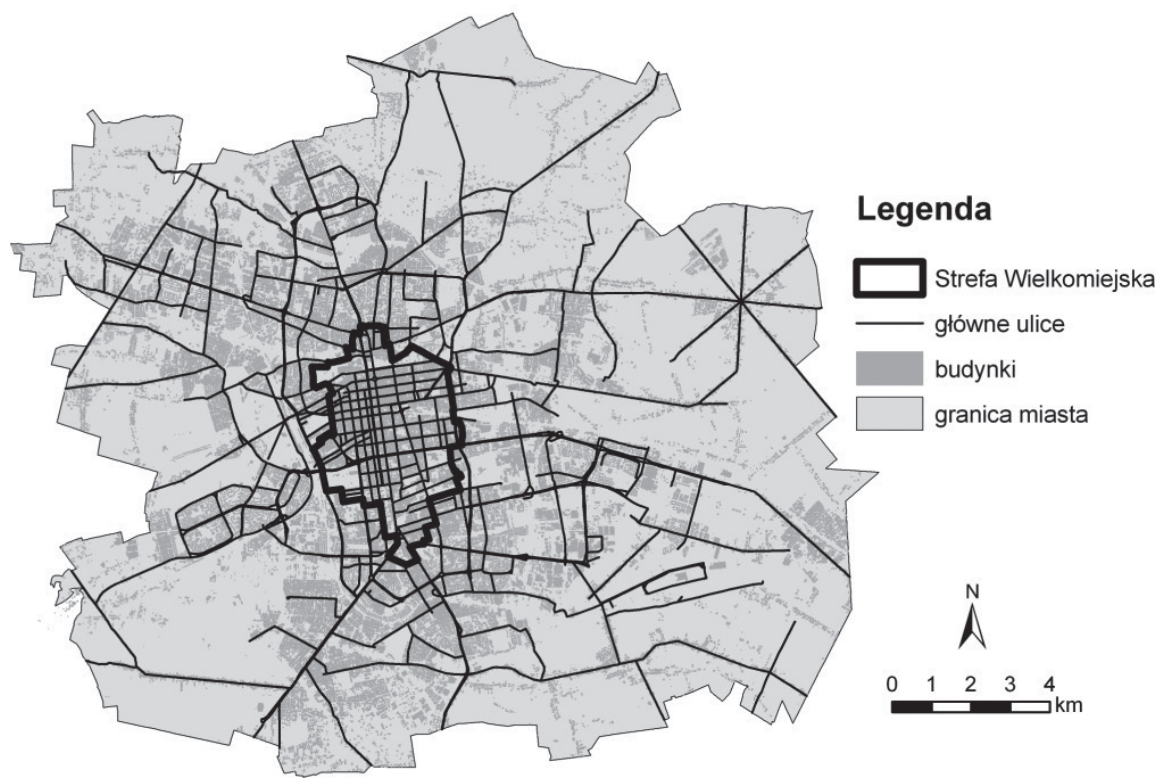

Rys. 1. Położenie Strefy Wielkomiejskiej w Łodzi

Źródło: opracowanie własne.

kompleksowej rewitalizacji i przywracania wysokiej wartości nieruchomości; będzie priorytetowa pod względem koncentracji inwestycji ${ }^{2}$.

Strefa Wielkomiejska ma powierzchnię $14 \mathrm{~km}^{2}$ (4,8\% powierzchni miasta), w $2010 \mathrm{r}$. zamieszkiwało ją ponad 140 tys. mieszkańców (19,7\%), a według Powiatowego Urzędu Pracy mieszkało tutaj 10287 bezrobotnych osób (30,4\% spośród wszystkich łódzkich bezrobotnych) ${ }^{3}$. Przytoczone liczby oznaczają 6,35 raza większą liczbę osób bezrobotnych w stosunku do powierzchni tego obszaru oraz 1,54-krotną nadwyżkę bezrobotnych w stosunku do liczby mieszkańców. Można więc uznać całą Strefę za jeden wielki obszar problemowy w zakresie bezrobocia (tabele 2-3). Łódzka Strefa nie jest jednak jednorodna - w dalszej części tekstu zostanie wykazana możliwość wyznaczenia na jej obszarze lokalnych miejsc koncentracji bezrobocia, czyli hotspotów.

Bazę danych udostępnioną przez Powiatowe Urzędy Pracy w Łodzi (PUP nr 1, ul. Milionowa 91, PUP nr 2, ul. Kilińskiego 102), stanowiącą podstawę do prowadzonych poniżej analiz, stanowił spis adresów zamieszkania bezrobotnych w Łodzi w $2010 \mathrm{r}$. Poza adresem obejmował on status osób pozostających bez pracy: bez wykształcenia średniego, bez kwalifikacji zawodowych, długotrwale bezrobotny, bezrobotny powyżej

\footnotetext{
2 Uchwała nr LV/1146/13 Rady Miejskiej w Łodzi z dnia 16 stycznia 2013 r. w sprawie Strategii przestrzennego rozwoju Łodzi $2020+$.

$3 \mathrm{Na} 35238$ zarejestrowanych w Łodzi bezrobotnych tylko 33849 osób posiadało adres zamieszkania podany odsetek odnosi się do liczby osób posiadających zameldowanie w Łodzi.
} 
50. roku życia, bez doświadczenia zawodowego, samotnie wychowujący dziecko do 18. roku życia, bezrobotny do 25. roku życia, bezrobotny niepełnosprawny, kobieta po urodzeniu dziecka, po odbyciu kary pozbawienia wolności, na stażu, na szkoleniu. Na podstawie danych adresowych dokonano ich geolokalizacji, a obszar obejmujący Strefę Wielkomiejską przedstawiono na rysunku 2.

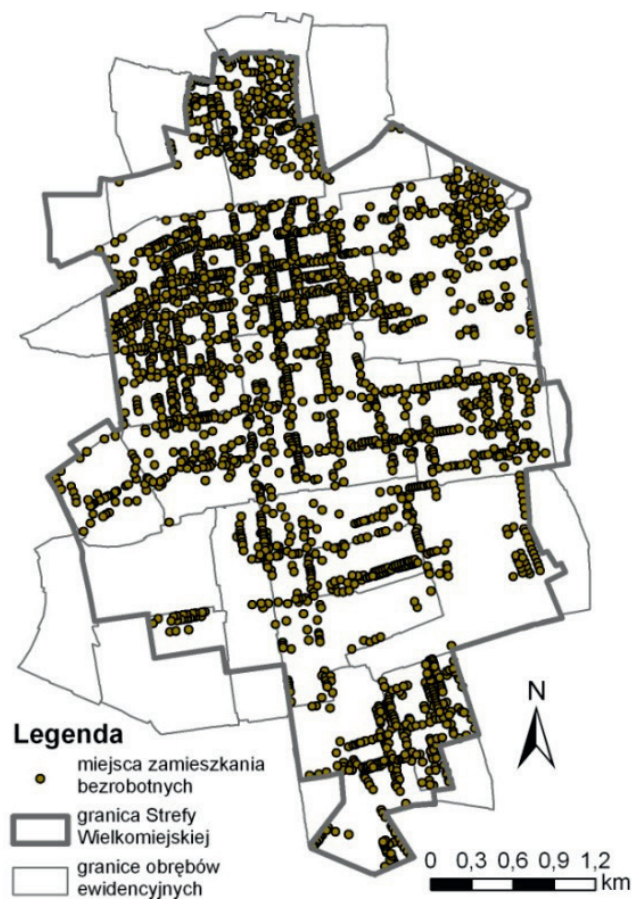

Rys. 2. Miejsca zamieszkania bezrobotnych w Strefie Wielkomiejskiej w Łodzi w 2010 r.

Źródło: opracowanie własne na podstawie danych PUP w Łodzi.

\section{Identyfikacja hotspotów bezrobocia}

W przypadku identyfikowania miejsc koncentrowania się różnych zjawisk do najczęściej stosowanych metod analizy przestrzennej można zaliczyć: kartogramy (rysunek 3a), kartodiagramy, mapy punktowe (rysunek 2), autokorelację lokalną i globalną I Morana, autokorelację Gi* Getisa-Orda, estymatory gęstości jądrowej (rysunek 3b), grupowanie hierarchiczne bazujące na technice najbliższego sąsiada (rysunek 3c) czy metodę $k$-średnich ${ }^{4}$. Opracowując mapy za pomocą tych metod, zadano sobie pytanie

\footnotetext{
4 W tym opracowaniu wykorzystano tylko niektóre spośród wielu możliwości oferowanych przez narzędzia GIS; nie był możliwy opis wszystkich z nich. Szerzej przeanalizowano tylko te, które są częściej
} 


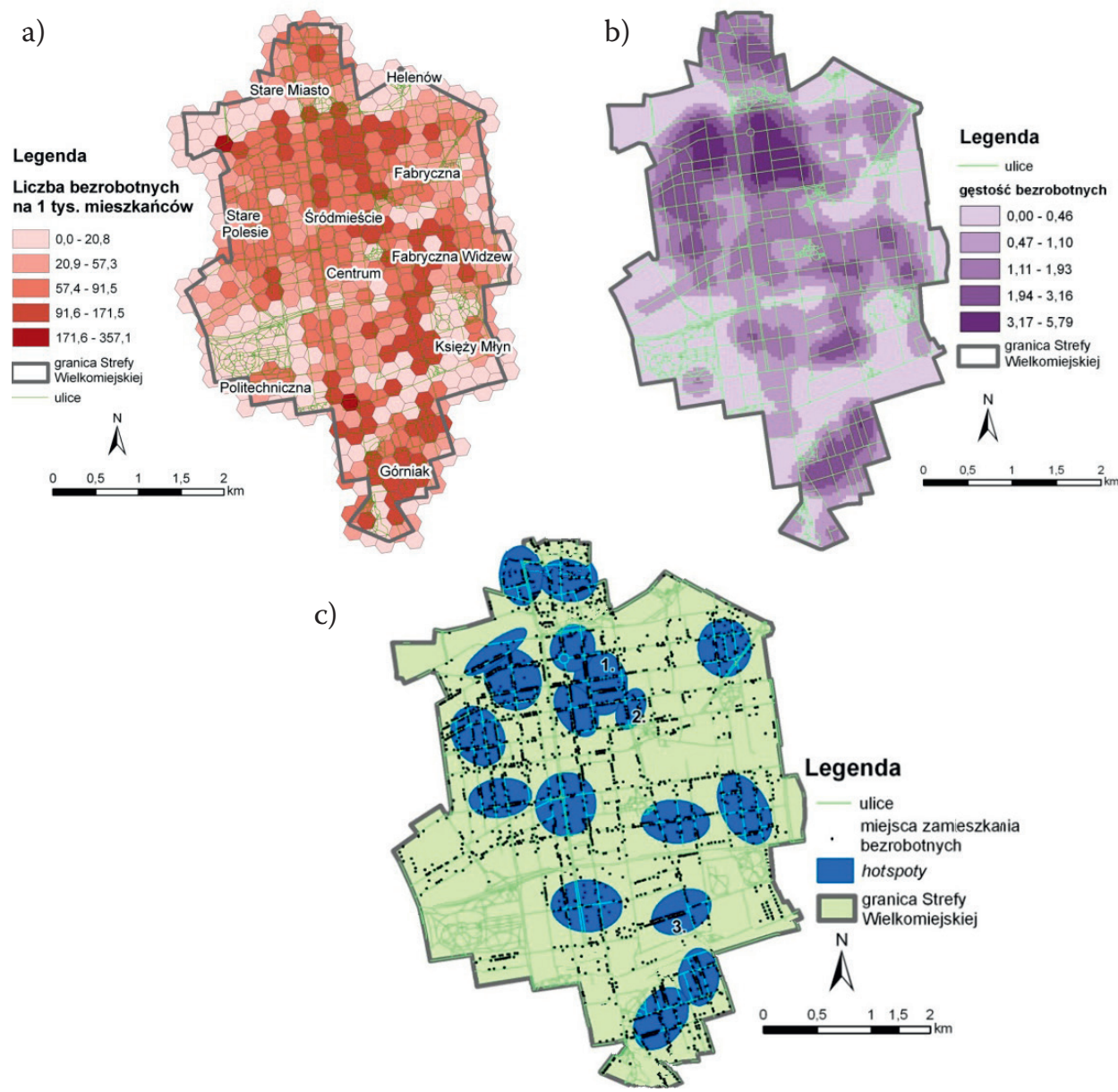

Rys. 3. Hotspoty bezrobocia w Strefie Wielkomiejskiej w Łodzi w 2010 r. wyznaczone metodą: a) kartogramu, b) estymacji gęstości jądrowej, c) hierarchiczną najbliższego sąsiada (oznaczenia wybranych hotspotów: 1. „Wschodnia”, 2. „Kilińskiego”, 3. „Abramowskiego”)

Źródło: jak w rysunku 2.

o uzyskaną efektywność wyznaczonych miejsc koncentracji bezrobocia, przy założeniu, że powinien być to niewielki wycinek przestrzeni miasta, na obszarze którego mieszka wiele bezrobotnych osób. Do rozwiązania tego problemu wykorzystano wskaźnik PAI, który został opisany w opracowaniu Spencera Chaineya z zespołem (2008, s. 14) $)^{5}$.

wykorzystywane i opisywane w literaturze, np. Chainey et al. 2002; Eck et al. 2005; Chainey et al. 2008; Hart, Zandbergen 2012; Crime modelling... 2013, i które były dostępne w aplikacjach: ArcGIS, CrimeSTAT IVi OpenGeoDa.

${ }^{5}$ Wskaźnik PAI (prediction accuracy index) skonstruowany jest w ten sposób, że w liczniku znajduje się odsetek bezrobotnych, których adresy zamieszkania zlokalizowane są na powierzchni wszystkich hotspotów. 
Wskaźnik jest tak skonstruowany, że dla całego badanego obszaru PAI = $1(100 \%$ lokalizacji występuje na $100 \%$ powierzchni); natomiast górna jego granica nie jest określona. Wartości omawianego wskaźnika dla wyznaczonych różnymi technikami hotspotów przedstawiono w tabeli 1. Okazało się, że najlepiej dopasowane hotspoty bezrobocia uzyskano przy zastosowaniu grupowania hierarchicznego metodą najbliższego sąsiada oraz estymacji gęstości jądrowej ${ }^{6}$.

Tabela 1

Porównanie skuteczności technik wyznaczania hotspotów

\begin{tabular}{|l|c|}
\hline \multicolumn{1}{|c|}{ Technika wyznaczania hotspotów } & Wskaźnik PAI \\
\hline Kartogram & 1,14 \\
Autokorelacja przestrzenna (I Morana) & 1,32 \\
Autokorelacja przestrzenna ( $G{ }^{*}$ Getisa i Orda) & 1,97 \\
Estymacja gęstości jądrowej & 2,14 \\
Metoda $k$-średnich & 1,12 \\
Grupowanie hierarchiczne metodą najbliższego sąsiada & 2,27 \\
\hline
\end{tabular}

Źródło: obliczenia własne na podstawie danych PUP w Łodzi.

W wyniku zastosowania procedury grupowania hierarchicznego na obszarze Strefy Wielkomiejskiej Łodzi zidentyfikowano 18 miejsc koncentracji bezrobocia, czyli hotspotów. Łącznie na ich obszarze mieszkało niecałe 55\% osób bezrobotnych z całej Strefy; zajmowały one $24 \%$ powierzchni Strefy. Przyglądając się rozmieszczeniu hotspotów bezrobocia na analizowanym obszarze, zauważyć można skupienia kilku z nich: na obszarze Starego Miasta, w północnej części Śródmieścia, na Starym Polesiu oraz na osiedlu Górniak. Wśród wszystkich miejsc koncentracji bezrobotnych szczególnie negatywnie wyróżniały się trzy hotspoty (rysunek 3c). Pierwszy, umownie nazwany "Wschodnia" (najwięcej, bo 28\% mieszkających tutaj bezrobotnych ma adres zameldowania przy tej ulicy), charakteryzuje największa liczba osób pozostających bez pracy.

Mianownik natomiast stanowi odsetek powierzchni zajmowanej przez hotspoty w powierzchni ogólnej. Generalnie o większej efektywności użytej techniki decydować będzie jak najwyższa wartość licznika, przy możliwie najniższej wartości mianownika. Innymi słowy: im więcej miejsc zamieszkania bezrobotnych znajdzie się na jak najmniejszej powierzchni hotspotów, tym wyższa będzie wartość wskaźnika PAI.

6 Grupowanie hierarchiczne bazujące na metodzie najbliższego sąsiada jest przydatne do prowadzenia analiz przestrzennych na podstawie zjawisk lokalizowanych w punktach - algorytm metody nie wymaga zliczania lokalizacji według jakichkolwiek obszarów. Zatem zaletą zastosowanej techniki hierarchicznej jest praca na danych adresowych (point pattern data). Jest to technika bardzo przydatna do bezpośredniej wizualizacji dyskretnych informacji o punktach w przestrzeni. Uzyskane obiekty graficzne - elipsy - w jednoznaczny sposób identyfikują hotspoty (Eck et al. 2005, s. 47). Wadą tej techniki jest natomiast uzyskany efekt wizualny - elipsy mogą bowiem nie odpowiadać faktycznemu rozmieszczeniu zjawiska, które lokuje się w punktach, na odcinkach ulic bądź w kwartałach zabudowy. Ponadto z dalszej analizy mogą zostać wyłączone lokalizacje, które nie zostały zaliczone do żadnego hotspotu. 
Na obszarze hotspotu „Kilińskiego” (48\% tutejszych bezrobotnych zameldowanych jest przy tej ulicy) największa jest gęstość osób bezrobotnych na 1 ha, natomiast hotspot „Abramowskiego" (62\% bezrobotnych posiada adres zameldowania przy tej ulicy) cechuje zdecydowanie największy udział bezrobotnych w ogólnej populacji mieszkańców tego obszaru (tabela 2).

Tabela 2

Podstawowe wskaźniki charakteryzujące bezrobocie na wybranych obszarach w Łodzi

\begin{tabular}{|c|c|c|c|}
\hline \multirow[b]{2}{*}{ Wybrane obszary } & \multirow{2}{*}{$\begin{array}{l}\text { Liczba osób } \\
\text { bezrobotnych }\end{array}$} & \multicolumn{2}{|c|}{ Liczba bezrobotnych } \\
\hline & & na 1 ha & $\begin{array}{c}\text { na } 1 \text { tys. } \\
\text { mieszkańców }\end{array}$ \\
\hline Łódź & 35238 & 1,2 & 49,4 \\
\hline Strefa Wielkomiejska & 10287 & 7,3 & 73,3 \\
\hline Hotspot „Wschodnia” & 680 & 30,4 & 93,0 \\
\hline Hotspot „Kilińskiego” & 231 & 31,3 & 99,8 \\
\hline Hotspot „Abramowskiego” & 301 & 17,9 & 129,9 \\
\hline
\end{tabular}

Źródło: jak w tabeli 1.

\section{Charakterystyka bezrobotnych z obszaru wybranych hotspotów}

Hotspoty bezrobocia cechują się nie tylko koncentracją przestrzenną osób pozostających bez pracy na obszarze miasta. Okazuje się ponadto, że bezrobotni tam mieszkający posiadają szczególnie negatywną charakterystykę w świetle statusu, który został dla nich określony w Powiatowym Urzędzie Pracy ${ }^{7}$. Analizując charakterystyki osób bezrobotnych zamieszkujących Strefę Wielkomiejską, można zauważyć, że stanowi ona w całości duży obszar problemowy (tabela 3). W porównaniu do adekwatnych charakterystyk dla całej Łodzi w Stefie są znacznie wyższe udziały osób nieposiadających wykształcenia średniego, kwalifikacji zawodowych i doświadczenia zawodowego. Ponadto jest tu względnie więcej osób bezrobotnych długotrwale ${ }^{8}$, niepełnosprawnych i samotnie wychowujących nieletnie dzieci. Poza tym niepokojący jest fakt, że tak niewielu zarejestrowanych bezrobotnych przebywało na stażu lub szkoliło się - zastana-

7 W tabeli 3 wymieniono 12 różnych charakterystyk/statusów bezrobotnych, które są określane w PUP podczas rejestracji. Przeciętnie osoba bezrobotna w Łodzi opisana jest poprzez 3 takie statusy, aczkolwiek były też takie osoby, które miały ich aż 8 naraz.

8 Bezrobocie długotrwałe dotyczy osób, które w okresie ostatnich dwóch lat pozostawały w rejestrze powiatowego urzędu pracy przez co najmniej 12 miesięcy. Jest to grupa bezrobotnych, którą najtrudniej zaktywizować, przy jednoczesnym ponoszeniu znacznych kosztów tej aktywizacji. Są to głównie osoby, które co prawda szukają aktywnie pracy, ale ich umiejętności, doświadczenie zawodowe (w znacznej części jest to młodzież i absolwenci jeszcze bez doświadczenia), a także wiek (osoby po 50. roku życia) powodują, że najtrudniej im dopasować ofertę zatrudnienia. 
wiające jest, dlaczego jest to tak mało popularna forma aktywizacji osób pozostających bez pracy.

Jak się jednak okazało, na obszarach wyróżnionych hotspotów „Wschodnia” i „Abramowskiego" charakterystyki zamieszkujących tam bezrobotnych posiadają jeszcze bardziej negatywny wymiar. Tylko nieco mniej jest tutaj bezrobotnych ze statusem powyżej 50. roku życia, co może wynikać z faktu, że mieszkańcy Strefy Wielkomiejskiej są generalnie przeciętnie młodsi niż mieszkańcy Łodzi. Mieszkających tutaj bezrobotnych wyraźnie częściej rejestrowano przy użyciu pozostałych statusów. W szczególności jest tutaj znacznie więcej osób bez średniego wykształcenia, bez kwalifikacji zawodowych, bez doświadczenia zawodowego oraz samotnie wychowujących nieletnie dzieci. Ponadto hotspot „Abramowskiego” zamieszkuje więcej osób o statusie długotrwale bezrobotny oraz po odbyciu kary pozbawienia wolności. Natomiast hotspot „Kilińskiego” negatywnie wyróżnia się „tylko” zwiększonym udziałem bezrobotnych bez wykształcenia średniego i bez kwalifikacji zawodowych.

Zatem i liczba bezrobotnych (bezwzględna, a także przeliczona na jednostkę powierzchni i 1 tys. mieszkańców), i charakterystyka ich statusu świadczą o tym, że wyróżnione trzy hotspoty są szczególnymi obszarami problemowymi w Strefie Wielkomiejskiej Łodzi.

Tabela 3

Charakterystyka statusu bezrobotnych (w \%)

\begin{tabular}{|c|c|c|c|c|c|}
\hline Status bezrobotnego & Łódź & $\begin{array}{c}\text { Strefa } \\
\text { Wielko- } \\
\text { miejska }\end{array}$ & $\begin{array}{l}\text { Hotspot } \\
\text { „Wschod- } \\
\text { nia” }\end{array}$ & $\begin{array}{l}\text { Hotspot } \\
\text { „Kiliń- } \\
\text { skiego" }\end{array}$ & $\begin{array}{c}\text { Hotspot } \\
\text { „Abramow- } \\
\text { skiego" }\end{array}$ \\
\hline Bez wykształcenia średniego & 57,8 & 68,8 & 75,1 & 72,6 & 83,0 \\
\hline Bez kwalifikacji zawodowych & 40,9 & 53,9 & 58,1 & 52,4 & 58,5 \\
\hline Długotrwale bezrobotny & 39,6 & 51,5 & 44,0 & 40,6 & 48,6 \\
\hline $\begin{array}{l}\text { Bezrobotny powyżej } 50 \text {. roku } \\
\text { życia }\end{array}$ & 33,0 & 32,5 & 30,9 & 28,8 & 30,6 \\
\hline Bez doświadczenia zawodowego & 14,6 & 17,0 & 18,0 & 15,6 & 19,0 \\
\hline Bezrobotny do 25. roku życia & 12,8 & 12,9 & 13,5 & 12,7 & 13,6 \\
\hline Bezrobotny niepełnosprawny & 11,5 & 12,5 & 12,7 & 9,9 & 12,6 \\
\hline $\begin{array}{l}\text { Samotnie wychowujący dziecko } \\
\text { do } 18 \text {. roku życia }\end{array}$ & 9,8 & 12,5 & 15,3 & 9,9 & 18,4 \\
\hline Kobieta po urodzeniu dziecka & 7,3 & 7,6 & 8,5 & 7,5 & 8,5 \\
\hline $\begin{array}{l}\text { Po odbyciu kary pozbawienia } \\
\text { wolności }\end{array}$ & 2,6 & 2,9 & 2,9 & 2,8 & 5,4 \\
\hline Na szkoleniu & 1,4 & 0,6 & 0,4 & 0,9 & 1,0 \\
\hline Na stażu & 0,6 & 2,1 & 2,4 & 2,4 & 2,4 \\
\hline
\end{tabular}

Źródło: obliczenia własne na podstawie danych z PUP w Łodzi (dotyczą tylko osób zarejestrowanych bezrobotnych posiadających adres zameldowania w Łodzi). 


\section{Podsumowanie}

Znajomość rozkładu przestrzennego oraz miejsc koncentrowania się problemów i patologii społecznych (np. bezrobocie, przestępczość, bieda czy alkoholizm) ma duże znaczenie przede wszystkim dla służb publicznych oraz administracji. Pozwala określić przyczyny tych zjawisk oraz planować politykę przeciwdziałania im. Skuteczność tych działań prewencyjnych uwarunkowana jest prawidłowym rozpoznaniem zjawiska oraz zidentyfikowaniem głównych miejsc/obszarów problemowych. W szerszej perspektywie skuteczność rozwiązywania problemów społecznych w znacznym stopniu stanowi poważne uwarunkowanie rozwoju, a dalsze przeciwdziałanie ich postępowi musi być uwzględnione w perspektywach rozwoju każdego miasta.

W wyniku przeprowadzonych analiz rozmieszczenia bezrobotnych możliwe było zlokalizowanie w Strefie Wielkomiejskiej Łodzi obszarów koncentracji bezrobocia, które w 2010 r. były najbardziej zagrożone nasileniem tego problemu społecznego. Zgodnie z oczekiwaniami Strefa Wielkomiejska w Łodzi w całości okazała się bardzo narażona na występowanie bezrobocia. Zastosowane metody i techniki analiz przestrzennych pozwoliły na identyfikację w tej Strefie wielu konkretnych miejsc, w których istnieje wysokie natężenie tego zjawiska. Niektóre z tych miejsc okazały się narażone nawet kilka razy bardziej niż wynosi średnia dla całego miasta. W szczególności należały do nich tereny przyległe do ulic: Wschodniej, Kilińskiego i Abramowskiego. W tych miejscach poza zwiększoną liczbą bezrobotnych stwierdzono, że były to osoby o szczególnie niekorzystnej charakterystyce: nie posiadały kwalifikacji, doświadczenia zawodowego i nawet średniego wykształcenia. Co szczególnie niepokojące - często osoby te pozostawały bez pracy od dłuższego już czasu.

W wyniku przeprowadzonych analiz okazało się, że większość osób bezrobotnych zamieszkuje najstarsze części Łodzi, o niskim standardzie zabudowy mieszkaniowej. W świetle tych i innych badań prowadzonych w Łodzi przez geografów i socjologów może to oznaczać, iż te części miasta sprzyjają rozwojowi negatywnych zjawisk społecznych. Dalsza ucieczka mieszkańców, których na to stać, do innych części miasta może tylko pogłębić skalę problemów na wskazanych w tym opracowaniu obszarach Strefy Wielkomiejskiej.

\section{Bibliografia}

Bartnicki S., 1991, Percepcja zagrożenia przestępczością - wstępna prezentacja wyników badań przeprowadzonych w 12 warszawskich osiedlach mieszkaniowych, "Conference Papers IGiPZ PAN” vol. 14.

Chainey S., Reid S., Stuart N., 2002, When is a hotspot a hotspot? A procedure for creating statistically robust hotspot map, [w:] Innovations in GIS 9: Socio-economic applications of geographic information science, eds. D. Kidner, G. Higgs, S. White, Taylor \& Francis, London.

Chainey S., Thompson L., Uhlig S., 2008, The utility of hotspot mapping for predicting spatial patterns, „Security Journal" vol. 21(1-2).

Crime modeling and mapping using geospatial technologies, 2013, ed. M. Leitner, Springer, Dordrecht-New York. 
Czekaj K., 1991, Mapy problemów społecznych jako narzędzie badawcze ekologii humanistycznej. Aspekty teoretyczne i empiryczne, [w:] Zagrożenia ekologiczne, warunki życia, wizje przyszłości, red. J. Wódz, Śląsk, Katowice.

Eck J., Chainey S., Cameron J., Leitner M., Wilson R., 2005, Mapping crime: Understanding hot spots, National Institute of Justice, Washington.

Grotowska-Leder J., 2001, Przestrzeń miejska a zjawiska upośledzenia społecznego (na przyktadzie Łodzi), [w:] Koncepcje teoretyczne $i$ metody badań geografii społeczno-ekonomicznej i gospodarki przestrzennej, red. H. Rogacki, Bogucki Wydawnictwo Naukowe, Poznań.

Hart T., Zandbergen P., Effects of data quality on predictive hotspot mapping, National Justice Research Service, Washington.

Kotus J., 2005, Społeczne dylematy w przestrzeni miejskiej, Bogucki Wydawnictwo Naukowe, Poznań.

Kwiatkowski E., 2002, Bezrobocie. Podstawy teoretyczne, PWN, Warszawa.

Mordwa S., 2013, Przestępczość i poczucie bezpieczeństwa w przestrzeni miasta. Przykład Łodzi, Wydawnictwo Uniwersytetu Łódzkiego, Łódź.

Mordwa S., 2014, Dysproporcje przestrzenne wybranych zjawisk patologii społecznych w Łodzi, [w:] Dysproporcje społeczne i gospodarcze w przestrzeni Łodzi. Czynniki, mechanizmy, skutki, red. A. Suliborski, M. Wójcik, Wydawnictwo Uniwersytetu Łódzkiego, Łódź.

Prawelska-Skrzypek G., Porębski W., 2003, Obszary deprywacji w Krakowie oraz zmiany w ich rozmieszczeniu w latach 1992-2001, „Nierówności Społeczne a Wzrost Gospodarczy” nr 2.

Skorupowa J., Czepczyński M., 1999, Relikty gdyńskich slumsów w przestrzeni miejskiej, [w:] Zróżnicowanie przestrzenne struktur społecznych $w$ dużych miastach. XI Konwersatorium Wiedzy o Mieście, red. I. Jażdżewska, Łódzkie Towarzystwo Naukowe, Łódź.

Stach A., Wysocka P., 2014, Zastosowanie metody krigingu Poissona w badaniach rozkładu przestrzennego problemów społecznych na przyktadzie Poznania, „Acta Universitatis Lodziensis. Folia Geographica Socio-Oeconomica” No. 16.

Uchwała nr LV/1146/13 Rady Miejskiej w Łodzi z dnia 16 stycznia 2013 r. w sprawie Strategii przestrzennego rozwoju Łodzi 2020+.

Wallis A., 1971, Socjologia i kształtowanie przestrzeni, PIW, Warszawa.

Weltrowska J., Kisiała W., 2014, Obszary koncentracji ubóstwa w strukturze przestrzennej miasta (na przyktadzie Poznania), „Prace Naukowe Uniwersytetu Ekonomicznego we Wrocławiu” nr 331.

Węcławowicz G., 2001, Przestrzeń ubóstwa - nowy czy stary wymiar zróżnicowania społeczno-przestrzennego w miastach Polski, „Przegląd Geograficzny” nr 73(4).

Zborowski A., 2010, Społeczny aspekt rewitalizacji, [w:] Rewitalizacja miast polskich-diagnoza, red. Z. Ziobrowski, W. Jarczewski, Instytut Rozwoju Miast, Kraków. 